\title{
"Challenges to the growth of African immigrant-owned businesses in selected craft markets in Cape Town, South Africa"
}

\begin{tabular}{ll} 
AUTHORS & $\begin{array}{l}\text { Samson Nambei Asoba } \\
\text { Robertson K. Tengeh }\end{array}$ \\
& $\begin{array}{l}\text { Samson Nambei Asoba and Robertson K. Tengeh (2016). Challenges to the } \\
\text { growth of African immigrant-owned businesses in selected craft markets in Cape }\end{array}$ \\
Town, South Africa. Investment Management and Financial Innovations, 13(3-2), \\
ARTICLE INFO & http://dx.doi.org/10.21511/imfi.13(3-2).2016.14 \\
\hline DOI & Monday, 10 October 2016 \\
\hline RELEASED ON & "Investment Management and Financial Innovations" \\
\hline JOURNAL & LLC "Consulting Publishing Company "Business Perspectives" \\
\hline FOUNDER &
\end{tabular}

NUMBER OF REFERENCES

0

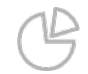

NUMBER OF FIGURES

0

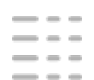

NUMBER OF TABLES

0

(C) The author(s) 2022. This publication is an open access article. 


\title{
Samson Nambei Asoba (South Africa), Robertson K. Tengeh (South Africa) Challenges to the growth of African immigrant-owned businesses
in selected craft markets in Cape Town, South Africa
}

\begin{abstract}
This paper sought to ascertain the factors that impact on the growth of African immigrant-owned craft businesses in selected craft markets. The purposive and snowball non-probability sampling technique was deemed to be the best method to use in this study to select the respondents. The study utilized a mixed method approach to collect and analyze data. Questionnaires (quantitative) were administered to 122 African immigrant entrepreneurs, and in-depth interviews (qualitative) were conducted with the three municipality managers responsible for the four selected craft markets. The quantitative data were analyzed using the Statistical Packages for Social Sciences (SPSS) software, and face-to- face interviews were analysed by content analysis. Pushed by the need to survive and pulled by the many tourists in South Africa, African immigrant entrepreneurs turned to the craft business Seasonal and irregular nature of trade, competition, and xenophobia were noted to be the main growth challenges. Recommendations were made to the relevant stakeholders.
\end{abstract}

Keywords: African immigrant entrepreneur, business growth, survivalist businesses, craft markets, SMEs. JEL Classification: M10, M13.

\section{Introduction}

The past 20 years have seen an unprecedented influx of African immigrant entrepreneurs into many cities in South Africa. An appreciable proportion of these immigrants settled in Cape Town for reasons such as its relative tranquillity (Van Eeden, 2011). The area surrounding Cape Town provides a variety of destinations for visitors, for example, Table Mountain, Robben Island, Cape Point, the South African Museum, Camps Bay and further afield, the Garden Route. According to O'Hagan (2001), the city of Cape Town offers numerous informal flea markets, including, Greenmarket Square, Stellenbosch craft market, Franschhoek craft market and Hout Bay craft market.

Due to a number of push and pull factors, the African immigrants found themselves dominating the craft markets in Cape Town. For instance, it is believed that the majority of craft retail outlets are owned by African immigrant entrepreneurs who are forced into self-employment, because they are largely unable to secure formal employment (Kaiser and Associates, 2005; Mikolo, 2007). This comes against the backdrop that they are discriminated against in the labor market and often under-paid when they find a job (Tengeh, Ballard \&Slabbert, 2011; El Bouk, Vedder\&tePoel, 2013; Fatoki, 2014a). South Africans are given first preference when filling any job vacancy (Peberdy, 2000).

The numerous hurdles to be content with often limit

(C) Samson Nambei Asoba, Robertson K. Tengeh, 2016.

Samson Nambei Asoba, Mr., Department of Entrepreneurship \& Business Management, Faculty of Business \& Management Sciences, Cape Peninsula University of Technology, South Africa.

Robertson K. Tengeh, Senior Lecturer and Research Coordinator, Department of Entrepreneurship \& Business Management, Faculty of Business \& Management Sciences, Cape Peninsula University of Technology, South Africa.
African immigrant-owned businesses to survivalist and micro enterprises (Khosa\&Kalitanyi, 2014). In fact, it has been noted that a significant proportion of these African immigrant-owned businesses do not grow to small and medium-size businesses (Elk, 2004; Hay, 2008; Rogerson \& Rogerson, 2011; Fatoki \& Garwe, 2010). As Hay (2008) puts it, many craft businesses do not grow beyond the survivalist and micro level. Worst still, the Organisation for Economic Cooperation and Development (OECD, 2010) notes that the immigrant-owned businesses have a lesser chance of survival, when compared to local businesses.

The fact that immigrant-owned businesses do not grow is a cause of concern. This is particularly so, because the growth of African immigrant-owned businesses in craft markets would not only offer employment opportunities to African immigrants and the local population, but would also contribute to the Gross Domestic Product (GDP) of South Africa (Kalitanyi\& Visser, 2010; Makhitha, 2015).

Though discerned to be a significant contributor to the socio-economic development of South Africa, the plight of immigrant-owned businesses has been largely neglected in policy and support initiatives over the past decades (Hunter \& Skinner, 2001; Kaiser \& Associates, 2003; Kaiser \& Associates, 2005; Rogerson, 2010a; Rogerson, 2010b; Tengeh et al., 2011; Tengeh 2013; Fatoki, 2014a). Notwithstanding the prevalence of these studies, little attention has been given to the factors that affect the growth of African immigrant-owned craft businesses. More so, the factors that inhibit these businesses moving from survivalist and micro phase to the formal SME cohort have not been studied in the context of craft businesses in South Africa. Accordingly, the objective of this study was to determine the challenges that African immigrant-owned craft businesses faced during the growth phase. 


\section{Literature review}

The literature review was conducted under the following themes: immigrant entrepreneurship, the importance of immigrant entrepreneurship, business growth, and challenges to the immigrant-owned businesses.

Immigrant entrepreneurship as a social phenomenon has intrigued many researchers over time, yet the concept is still in its developmental phase. Hence, a number of definitions - mostly "hybrids of entrepreneurship" have emerged. Put simply, immigrant entrepreneurship refers to entrepreneurial activities carried by immigrants in a country other than theirs, either through personal efforts or with assistance from acquaintances in the host or country of origin (Tengeh, 2011). The businesses owned and run by immigrants are referred to as immigrant-owned businesses. Thus, the term African immigrant entrepreneurship is utilized to describe the case where the process of entrepreneurship is carried out by an African immigrant in South Africa (Tengeh, 2011).

\subsection{Relevance of immigrant entrepreneurship.} Vinogradov and Isaksen (2007) point out that, in recent years, small businesses have benefited both immigrants and the host countries. Kloosterman and van der Leun (1999) maintain that immigrant entrepreneurship contributes to the host country's economic and social welfare through therevitalization of declining neighborhoods, introduction of new and cheap products and opening of trade links between countries. Furthermore, it is believed that immigrant entrepreneurs can serve as role models to both fellow immigrants and citizens of the host country. This view is supported by Minghuan (2000) who states that immigrant entrepreneurs may act as selfappointed leaders in the community and, thus, contribute to the integration of immigrants and local people.

A number of authors concur that immigrant entrepreneurs may generate employment opportunities for both immigrants and natives, therefore, contributing poverty reduction and economic growth (Kloosterman\& van der Leun, 1999; Fairlie, 2008; Kalitanyi\& Visser, 2010; Tengeh, 2011). Particularly important to the South African economy is the magnitude of the skills that can be transferred from immigrant to nonimmigrant employees, and the resultant effect that this may have on economic growth and development.

1.2. Growth of a business. There is no generally accepted definition, tool, method nor criterion for measuring growth and a number of scholars have gauged this differently. For instance, El Bouk et al. (2013), Birley and Westhead (1990), Altinay and Altinay (2008), Fatoki and Garwe (2010) alluded to one or combination of changes in sales, assets, employment, productivity and profit margins. In this paper, the concept of growth alludes to Africanowned craft businesses that have been in existence for more than 42 months and have successfully progressed from the survivalist and micro-phase to the small business phase (Naman\&Slevin 1993, cited by Altinay\&Altinay, 2008).

\subsubsection{Growth challenges of immigrant-owned} businesses. Generally, survivalist and micro entrepreneurs face more severe sales and income fluctuation than persons employed in traditional jobs. The seasonality and irregular nature of trade make it difficult to forecast. Khosa and Kalitanyi (2014) found that sales are very high in summer months and drop drastically during winter. Making reference to sales and income fluctuations, the V\&A Waterfront (2013) notes that African immigrants selling crafts experience the greatest sales volume during the festive season, because it is the peak season for tourists in South Africa. Khosa and Kalitanyi (2014) recommend that African immigrants form partnerships with locals to minimise cost and to gain access to government grants. Furthermore, Chikamhi (2011) points out that the craft markets were poorly designed and the weather pattern in Cape Town disrupts trading during the winter season, thus limiting the possibility of growth.

As one of the challenges, xenophobia refers to the intense dislike or fear of foreigners by citizens of the host country. The word xenophobia is derived from the Greek "xenos" meaning stranger or foreigner and "phobos" meaning fear. Xenophobic violence has gained particular relevance since 2008 in South Africa. Two prominent waves of anti immigrant attacks swept a number of townships in South Africa in 2008 and 2015, in which immigrant-owned shops were looted, and a number of deaths registered (Mail \& Guardian, 2015). Immigrants tend to invest cautiously or stand to lose everything should another attack happen.

Financial resources are needed to spur up business growth. Lack of access to financial resources has been reported to be a major hindrance to the survival and growth of immigrant-owned businesses (Fatoki \&Garwe, 2010; Tengeh et al., 2011). A number of authors have blamed this banks insistence collateral and other requirements inherently discriminate against immigrants (Kaiser \& Associates, 2003; Fatoki \&Garve, 2010, Tengeh et al., 2011; Tengeh, 2013; Khosa\&Kalitanyi, 2014; El Bouk et al., 2013). Insightfully, Fatoki (2014a) 
implores investigation into immigrant entrepreneur's access to formal finance, especially from the demand and supply side perspectives.

Businesses or organizations that serve the same market or satisfy the same needs tend to competitors. Given that many African immigrant businesses tend to serve the same niche markets, competition makes growth a challenge for the less competitive. In a related study, Khosa and Kalitanyi (2014) observed that the majority of African immigrant entrepreneurs felt that competition is particularly intense in Cape Town, and this affects profitability and growth. DEDKZN and SEDA (2007) argue that competition occurs not only within South African businesses (African immigrant businesses and non-African immigrant businesses) but also from international trade with China and India. Rogerson (2010b) suggests that crafters should constantly produce new, innovative craft products to meet the challenge in both domestic and foreign markets.

Entrepreneurial skills are crucial for the survival and growth of a business. Khosa (2014) share similar views and found that entrepreneurial skills are critical for the survival and growth of a business. Stretching entrepreneurial skills, Wickham (2001) and Nieman and Nieuwenhuizen (2009) include venture innovation, potential for growth, and strategic objectives. The element of strategic objectives includes market target, market development, market share and market position. Van Rensburg (2010) states that entrepreneurial skills include creativity and innovation, calculated risk and determination.

The ability to communicate in the language spoken in any market setting impacts positively on success. Language is a hindrance to immigrant entrepreneurship where an immigrant cannot communicate in the host-country language (Hunter \& Skinner, 2001; Levent et al., 2003; Habiyakare et al., 2009). In a related study, Hunter and Skinner (2001) noted a respondent that remarked that: "People shout at me, because I cannot speak Zulu". This language barrier affects customer relationships. Therefore, African immigrant entrepreneurs must be able to communicate effectively in the host country in which they conduct their business. Beyond this, language proficiency allows immigrants the benefits of integration into a community, access to business advice, and bank loans among others.

Crime and corruption impact negatively on the business. In 2007, South Africa was listed as one of the five most murderous nations (UNODC, 2007). Between 2010 and 2011, business robberies increased by $0.9 \%$ and of particular concern is the fact that 13277 robberies cases were recorded in Cape Town Central (South Africa, SAPS, 2011). With crime on the rise, Fatoki and Garwe (2010), point out that the effect of crime on business is glaring in South Africa. Hence, business owners tend to focus more on operational matters rather than staying ahead of competitors. The increasing expenditure on crime prevention deterred the growth of most businesses.

\section{Research design and methodology}

Following the counsel of scholars such as Zikmund, Babin, Carr and Griffin, (2010), and Brynard and Hanekom, (2006), the population of this study comprised African immigrants at the selected craft markets and the municipality managers responsible for managing the selected markets. This study focused on four craft markets in the Cape Town area: Greenmarket Square in the central business district of Cape Town, Stellenbosch craft market, Franschhoek craft market and Hout Bay craft market. Franschhoek is a small farming town within the jurisdiction of Stellenbosch Municipality. Hout Bay is a small fishing town within the jurisdiction of the City of Cape Town. The researcher selected these markets, because they are very popular tourist markets.

In line with Khan (2008), the sample frame of this study constitutes African immigrant entrepreneurowned businesses that are three or more years old, located in one of the selected markets. The municipality managers of the selected markets were eligible for selection.

According to Oppong (2013), purposive sampling is a method of sampling in which the researcher selects participants based on their knowledge or experience of the topic being researched. The purposive and snowball non-probability sampling technique was deemed the best method to use in this study, because the researcher had the data on the numbers of stalls in each craft market, but could not identify the African immigrant entrepreneurs. In snowball sampling, a few potential respondents are identified, to begin with and then asked to recommend others they may know who also meet the required criteria for inclusion in the study (Tengeh, 2011). In fact, Tengeh (2011) asserts that snowball sampling is useful when it is very difficult to approach the participant directly.

The Raosoft (2009) software was utilized to calculate the sample size and 122 was adopted for the study. The projected sample size consisted of 117 stalls at Greenmarket Square craft market, 25 stalls at Stellenbosch craft market, 21 stalls at Franschhoek craft market and 21 stalls at Hout Bay craft market. With a total number of 178 stalls, and aiming to uphold a $95 \%$ confidence level (i.e., $5 \%$ 
error margin), the ideal sample size as recommended by the calculator was 122; the response distribution is $50 \%$; and the recommended sample size is 122 .

Aiming to maximize the benefits of both methods, a blended approach was adopted to collect and analyze the data. The mixed research method is premised on collecting data using both quantitative and qualitative research methods in a single study, to understand a research problem (Johnson, Onwuegbuzie\& Turner, 2007). According to Green, Caracelli and Graham (1989, cited by Creswell \& Clark, 2011), the reasons for choosing a mixed method approach include, but not limited to the use of the result of one method to develop or inform the other method. Hence, it enhances correspondence and corroboration of the results of different methods. Beyond the benefits of triangulation mentioned earlier, the researchers believed that the mixed method approach was the most suitable for this study, as it was benchmarked against other related and recently published studies such as Tengeh et al., (2011) and Khosa and Kalitanyi (2014). The questionnaire was designed to accommodate 5-point Likert scale questions besides closed - and open-ended questions and multiple answer questions. Questions were formulated to capture growth and to measure the difference between the current and start-up turnover. Furthermore, the researcher utilized the interview guide to conduct in-depth face-to-face interviews to solicit information from each of the three municipal managers.

Though integrated at the end, the quantitative and qualitative data were analyzed in different phases. Firstly, quantitative data were analyzed separately using the SPSS. Secondly, qualitative data collected from interviews were sorted into themes and specific categories. The categories were placed in line with the research question. The result of the qualitative tool was, then, carefully aligned and integrated with the results of the quantitative method.

\section{Results and discussions}

3.1. Background characteristics of the respondents. Looking at the profile and characteristic of the participants, it emerged that the majority of respondents weremale $(70.8 \%)$, while only $29.2 \%$ were females. Interestingly, $35.5 \%$ of the respondents were between the ages of 20 to 40 years and a slight majority of $36.4 \%$ were between 41 to 60 years. In the same vain, $28.1 \%$ of respondents were over 60 years. In terms of marital status, $16.5 \%$ of respondents were single, while $69.4 \%$ were married. The majority $(18.0 \%)$ of respondents hailed from Cameroon and Zimbabwe respectively, followed by the Democratic Republic of Congo with $16.4 \%$. Only $0.8 \%$ of the respondents came from Egypt.

Approximately sixty percent (59.8 \%) of therespondents operated at Greenmarket Square, while $17.2 \%$ operated at Stellenbosch craft market. A slightmajority $(60.3 \%)$ of respondents had a secondary or high school education. This was followed by $19.0 \%$ who had been to auniversity, and only $2.5 \%$ of the respondents had no formal education.

The sample for the personal interviews was made of 3 municipal managers drawn from each site, who had 8, 11 and 35 years of work experience correspondingly. Hence, the managers were in a privilegedposition to correlate the entrepreneur's claims with rich in-depth information. The managers unanimously established that their role was to create an enabling environment for entrepreneurs and to ensure that the entrepreneurs comply with the by-laws of the municipality. This finding is supported by those of Pahwa, Bester, Nieuwenhuyzen, Dawood, Pieterse, Kane, Schlemer, Bot, Hamilton, Madel\& Eden (2006), Masonganye (2010) and Gudlhuza (2012). According to Pahwa et al. (2006), municipalities aim to be proactive in business support both at the provincial and national levels. Verbatim reports that captivated the role of the municipal managers included the following from participant 1 :

"The role of municipality firstly is to create an enabling environment for crafters. Our second role also is the development of crafters to run their business in business principles. Thirdly, the management of those sites, and to ensure they comply with the by-laws of the municipality. So we link very closely with our law enforcement".

3.2. Other results. Firstly, seasonality and the irregularity of trade emerged as one of thechallenges that African immigrants-owned craft businesses faced a number during growth phase. According to Table 1, the overwhelming majority $(65 \%)$ of the respondents agreed that the seasonal and irregular nature of trade makes it difficult to forecast, thus, limiting the possibility of growth, whereas only $14.1 \%$ respondents disagreed. This findingis supported by Chikamhi (2011) who points out that the craft markets are poorly designed and the weather pattern in Cape Town disrupts trading during the winter, thus, limiting the possibility of growth.

Table 1. The seasonal and irregular nature of trade makes it difficult to forecast

\begin{tabular}{|c|l|c|c|}
\hline \multicolumn{2}{|c|}{} & Frequency & Valid percent \\
\hline \multirow{4}{*}{ Valid } & No importance & 10 & 8.3 \\
\cline { 2 - 4 } & Some importance & 7 & 5.8 \\
\cline { 2 - 4 } & Moderate importance & 25 & 20.8 \\
\hline
\end{tabular}


Table 1 (cont.). The seasonal and irregular nature of trade makes it difficult to forecast

\begin{tabular}{|l|l|c|c|}
\hline \multicolumn{2}{|c|}{} & Frequency & Valid percent \\
\hline \multirow{4}{*}{} & Very important & 35 & 29.2 \\
\cline { 2 - 4 } & Extremely important & 43 & 35.8 \\
\cline { 2 - 4 } & Total & 120 & 100.0 \\
\hline Missing & No response & 2 & \\
\hline Total & 122 & \\
\hline
\end{tabular}

Secondly, Xenophobia emerged as one of the challenges to business growth. As recounted in Table 2, an overwhelming majority $(66.9 \%)$ of the respondents concurredthat xenophobia is a challenge to the growof a business, whereas $26.4 \%$ disagreed. This verdict resonates with Khosa (2014) who established the same with respect to the growth of African immigrantowned businesses in Cape Town. One may argue that thisresult has been positively influenced by the fact the most-recent xenophobic attack in April 2015 was still fresh on the minds of the respondents at the time data collection.

Table 2. Xenophobia is a challenge to grow my business

\begin{tabular}{|c|c|c|c|}
\hline & & Frequency & Valid percent \\
\hline \multirow{6}{*}{ Valid } & No importance & 23 & 19.0 \\
\hline & Some importance & 9 & 7.4 \\
\hline & $\begin{array}{l}\text { Moderate } \\
\text { importance }\end{array}$ & 8 & 6.6 \\
\hline & Very important & 19 & 15.7 \\
\hline & $\begin{array}{l}\text { Extremely } \\
\text { important }\end{array}$ & 62 & 51.2 \\
\hline & Total & 121 & 100.0 \\
\hline $\begin{array}{l}\text { Missin } \\
\mathrm{g}\end{array}$ & No response & 1 & \\
\hline \multicolumn{2}{|r|}{ Total } & 122 & \\
\hline
\end{tabular}

Relating the above results to the interviews held with municipal managers, participant 1 noted that:

"We must not forget there is something like xenophobic behavior that can be one of the challenges - the fact that people can stereotype people. For example, if you are coming from Nigeria and if Nigerians are smuggling drugs, the people assume every Nigerian smuggles drugs. It happens all over the world".

Participant 1's assertion correlates the findings of Peberdy (2000) and Hunter and Skinner (2001). Both studies found that South Africans are xenophobic, and this informs the "popular" descriptions of African immigrants as illegal, uneducated, job-takers, and so forth.

Thirdly, the participants reported a lack of credit facilities as a challenge to growth. The results in Table 3 show that a slight majority (54.2\%) of the respondents agreed that the lack of credit facilities is a challenge to growth, whereas $28 \%$ disagreed. This result correlates those of Rogerson (2010b) who suggests that the core challenge to SMMEs is how to secure finance for either start-up or cash flow. Cash flow is critical to obtain material, equipment, skilled labor and premises. Given that bank's funding is driven by asset-based assessments and appropriateness of ideas, it is suggested that new funding mechanisms be introduced, possibly by government, to make seed capital available to entrepreneurs without the stringent requirement of commercial banks (GEM, 2013).

Table 3. Lack of credit facilities is a challenge to growth

\begin{tabular}{|l|l|c|c|}
\hline \multicolumn{2}{|c|}{} & Frequency & Valid percent \\
\hline Valid & No importance & 23 & 19.5 \\
\cline { 2 - 4 } & Some importance & 10 & 8.5 \\
\cline { 2 - 4 } & Moderate importance & 21 & 17.8 \\
\cline { 2 - 4 } & Very important & 30 & 25.4 \\
\cline { 2 - 4 } & Extremely important & 34 & 28.8 \\
\cline { 2 - 4 } & Total & 118 & 100.0 \\
\hline Missing & No response & 4 & \\
\hline Total & 122 & \\
\hline
\end{tabular}

Fourthly, lack of support from DTI and the local government was noted as a challenge. Table 4 indicates that a slightlyless than majority (49.1\%) of the respondents disregard the lack of support from the DTI and local government as a challenge to business growth, while $42 \%$ of the respondents agreed with this statement and felt that the lack of support from the DTI and local government is not a challenge to growing a business. This finding is supported by Khosa and Kalitanyi (2014) who also found that the DTI does not assist immigrant entrepreneurs.

Table 4. Lack of support from DTI and local government

\begin{tabular}{|l|l|c|c|}
\hline \multicolumn{2}{|c|}{} & Frequency & Valid percent \\
\hline \multirow{4}{*}{ Valid } & No importance & 47 & 42.0 \\
\cline { 2 - 4 } & Some importance & 8 & 7.1 \\
\cline { 2 - 4 } & Moderate importance & 10 & 8.9 \\
\cline { 2 - 4 } & Very important & 15 & 13.4 \\
\cline { 2 - 4 } & Extremely important & 32 & 28.6 \\
\cline { 2 - 4 } & Total & 112 & 100.0 \\
\hline Missing & No response & 10 & \\
\hline Total & 122 & \\
\hline
\end{tabular}

Fifthly, the inability to communicate effectively in the local language was noted as a constraint. Table 5 reveals that the majority of $61.3 \%$ of participants disagreed that the inability to communicate effectively in local languages is a challenge to growth, whereas $25.2 \%$ of respondents agreed with this statement. This 
finding is corroborated by Levent et al. (2003) who found that language was a hindrance to immigrant entrepreneurship in Finland. Habiyakare et al. (2009) opine that immigrant entrepreneurs take a longer time to conduct business transactions because of language barriers. Hunter and Skinner (2001) also share the view that the local language is a problem to immigrants in South Africa. Khosa and Kalitanyi (2014) state that there are some benefits to be derived from the knowledge of local languages.

Table 5. Inability to communicate effectively in local language

\begin{tabular}{|l|l|c|c|}
\hline \multicolumn{2}{|c|}{} & Frequency & Valid percent \\
\hline \multirow{5}{*}{ Valid } & No importance & 58 & 48.7 \\
\cline { 2 - 4 } & Some importance & 15 & 12.6 \\
\cline { 2 - 4 } & $\begin{array}{l}\text { Moderate } \\
\text { importance }\end{array}$ & 16 & 13.4 \\
\cline { 2 - 4 } & Very important & 18 & 15.1 \\
\cline { 2 - 4 } & $\begin{array}{l}\text { Extremely } \\
\text { important }\end{array}$ & 12 & 10.1 \\
\cline { 2 - 4 } & Total & 119 & 100.0 \\
\hline Missing & No response & 3 & \\
\hline Total & & 122 & \\
\hline
\end{tabular}

Sixthly, competition emerged as a constraint to growth. The findings in Table 6 illustrate that an overwhelming majority of $(62.3 \%)$ respondents agreed that competition is a constraint to growth, whereas only $(24.6 \%)$ respondents disagreed. This outcome is supported by Khosa and Kalitanyi (2014) who found that competition is very tough among immigrant entrepreneurs in Cape Town. Competition occurs not only within South African businesses but also from international trade with China and India. Hernandez and Costanade (2007, cited by Rogerson \& Rogerson, 2011), share a similar view and state that low entry barriers increase the level of competition and it becomes difficult to increase productivity and growth.

Table 6. Competition is a constraint to growth

\begin{tabular}{|c|l|c|c|}
\hline \multicolumn{2}{|c|}{} & Frequency & Valid percent \\
\hline \multirow{4}{*}{ Valid } & No importance & 17 & 13.9 \\
\cline { 2 - 4 } & Some importance & 13 & 10.7 \\
\cline { 2 - 4 } & Moderate importance & 16 & 13.1 \\
\cline { 2 - 4 } & Very important & 27 & 22.1 \\
\cline { 2 - 4 } & Extremely important & 49 & 40.2 \\
\cline { 2 - 4 } & Total & 122 & 100.0 \\
\hline
\end{tabular}

Aligning the quantitative findings to the qualitative one, this is a sample quotation from one of the municipal managers (Participant three) with respect to competition as a restraint to grow:

"We have 20 traders at Hout Bay craft market. Out of 20 traders, 15 of them sell the same product. As a result, there is too much competition. I told the traders, if they can sell different products, they will make more money".

Perhaps one can align the foregoing to Giron et al. (2007), who noted that low entry barriers increase the level of competition and it becomes difficult to increase productivity and growth. Furthermore, DEDKZN \& SEDA (2007) state that competition of craft product occurs not only within South African businesses, but also from international trade with China and India.

Seventhly, crime was reported as another a challenge to growth. Table 7 below illustrates an overwhelming majority of $70(59.9 \%)$ participants who agreed that crime is a challenge to business growth, whereas 33 $(28.2 \%)$ of participants disagreed. This verdict aligns with Fatoki and Garwe (2010) who found that effects of crime are growing in South Africa. Hunter and Skinner (2001) state that crime is a serious obstacle to growth. Crime statistics reveal that 13277 robberies were recorded in central Cape Town in 2010/2011 (South Africa. SAPS, 2011). Because of the high crime rate, business owners are focusing more on operational matters rather than staying ahead of competitors.

Table 7. Crime is a challenge to growth

\begin{tabular}{|c|c|c|c|}
\hline & Frequency & Valid percent \\
\hline \multirow[t]{6}{*}{ Valid } & No importance & 25 & 21.4 \\
\hline & Some importance & 8 & 6.8 \\
\hline & Moderate importance & 14 & 12.0 \\
\hline & Very important & 32 & 27.4 \\
\hline & Extremely important & 38 & 32.5 \\
\hline & Total & 117 & 100.0 \\
\hline Missing & No response & 5 & \\
\hline \multicolumn{2}{|l|}{ Total } & 122 & \\
\hline
\end{tabular}

Lastly, lack of entrepreneurial skills emerged as a challenge to growth. Table 8 shows that a slight majority $(43.3 \%)$ of respondents disagreed that lack of entrepreneurial skills is a challenge to growth, while $34.7 \%$ of the participants agreed with the statement. Wickham (2001) and Khosa and Kalitanyi (2014) share similar views and found that entrepreneurial skills are critical for the survival and growth of a business.

Table 8. Lack of entrepreneurial skills is a challenge to growth

\begin{tabular}{|l|l|c|c|}
\hline \multicolumn{2}{|c|}{} & Frequency & Valid percent \\
\hline \multirow{4}{*}{ Valid } & No importance & 33 & 28.0 \\
\cline { 2 - 4 } & Some importance & 18 & 15.3 \\
\cline { 2 - 4 } & Moderate importance & 26 & 22.0 \\
\cline { 2 - 4 } & Very important & 24 & 20.3 \\
\cline { 2 - 4 } & Extremely important & 17 & 14.4 \\
\cline { 2 - 4 } & Total & 118 & 100.0 \\
\hline Missing & No response & 4 & \\
\hline Total & & 122 & \\
\hline
\end{tabular}




\section{Conclusion}

Against the backdrop that a notable proportion of African immigrant-owned survivalist and microbusinesses do not grow and develop into small and medium size enterprises (SMEs) in the selected craft markets, this paper sought to determine the associated factors. The study found that seasonal and the irregular nature of trade; competition; and xenophobia were the most precarious challenges to the growth of Africa immigrant craft businesses. Collaborating the results of the quantitative method, the municipal managers noted that xenophobia and competition were the most outstanding challenges that immigrant entrepreneurs in their jurisdiction faced. Emanating from the findings of this study, a number of recommendations were made.

\section{Recommendations}

The seasonal nature of trade is a challenge to do business in open stalls at craft markets. The researcher recommends that the municipality management erect permanent, weather-proof stalls at the selected markets. Permanent structures will help African immigrants by minimising the cost of damages to products caused by wind and rain, especially during the Cape winter months.

Xenophobia was stated as a challenge to the growth of African immigrant entrepreneur businesses. The researcher recommends that the municipality managers encourage anti-xenophobic sentiment through workshops and advertise the benefits of integrating African immigrant entrepreneurs into the local communities.

Competition was identified as a challenge during the growth phase of craft businesses. The researcher recommends that municipality managers accept new applicants only if they bring rare products which are different from the existing products at the craft market. The researcher also recommends that the municipality should organize workshops to educate African immigrant entrepreneurs on the benefits of selling unique products at the craft market.

Access to finance was identified as a crucial factor to enable the African immigrant entrepreneurs to grow their craft businesses. The researcher recommends intervention by the municipality managers to persuade these monetary agencies to extend their funding assistance to include deserving African immigrant entrepreneurs. Besides financial assistance, the DTI could provide mentorship to African immigrant entrepreneurs.

\section{Suggestions for future research}

The researchers believe that continuing research will assist in improving current circumstances of African immigrant entrepreneurs and create an environment which is conducive to them starting and growing their craft businesses in South Africa.

This study focused mainly on factors affecting the growth of African immigrant-owned businesses. The study was limited to handmade craftware sold in four selected craft markets, being Greenmarket Square, Stellenbosch, Franschhoek and Hout Bay. Future studies should focus on other crafts and other craft markets in South Africa.

Comparative studies should be conducted on African immigrant-owned craft businesses in other countries. This will enable policy-makers to understand African immigrant-owned craft businesses in a more holistic manner.

\section{References}

1. Altinay, L. and Altinay, E. (2008). Factors influencing business growth: the rise of Turkish entrepreneurship in the UK. International Journal of Entrepreneurial Behaviour\& Research, 14(1), pp. 24-46.

2. Basu, A. and Goswami, A. (1999). South Asian entrepreneurship in Great Britain: factors influencing growth, International Journal of Entrepreneurial Behaviour\& Research, 5(5), pp. 251-275.

3. Birley, S. and Westhead, P. (1990). Growth and performance contrasts between 'types' of small firms, Strategic Management Journal, 11(7), pp. 535-57.

4. Brynard, P.A. and Hanekom, S.X. (2006). Introduction to research in management-related fields. Pretoria: Van Schaik.

5. Chikamhi, T. (2011). Exploring the challenges facing micro enterprise immigrant traders in the Western Cape Metropole: Greenmarket Square and Hout Bay Harbour Markets. Master's thesis, University of Cape Town, Cape Town.

6. Creswell, J.W. and Clark, V.P. (2011). Designing and conducting mixed methods research. $2^{\text {nd }}$ ed. Thousand Oaks, CA: SAGE.

7. DEDKZN (Department of Economic Development Kwazulu Natal) \& SEDA (Small Enterprise Development Agency). 2007. Art and Craft Trade Directory. http://www.seda.org.za/Publications/Publications/ SEDA\%20SBM\%202009.pdf [23 October 2014].

8. El Bouk, F. Vedder, P. and te Poel, Y. (2013). The networking behavior of Moroccan and Turkish immigrant entrepreneurs in two Dutch neighborhoods: The role of ethnic density, Ethnicities, 13(6), pp. 771-794.

9. Elk, E. (2004). The South Africa Craft Sector. Cape Craft \& Design Institute, Cape Town, South Africa. www.capecraftdesign.org.za [12 January 2014]. 
10. Fairlie, R.W. (2008). Estimating the contribution of Immigrant business owners to the U.S. economy. Washington, DC: Small Business Administration Office of Advocacy, Working Paper. http://www.sba.gov/adro/research/rs 334tot.pdf [12 December 2014].

11. Fatoki, O. and Garwe, D. (2010). Obstacles to growth of new SMEs in South Africa: a principal component analysis approach, African Journal of Business Management, 4(5), pp. 729-738. http://www. academicjournals.org/AJBM.ISSN 1993-8233. [12 November 2014].

12. Fatoki, O. (2014). Immigrant entrepreneurship in South Africa: current literature and research opportunities, Journal of Social Sciences, 40(1), pp. 1-7.

13. GEM, (Global Entrepreneurship Monitor). (2013). South Africa report. Twenty years of democracy. Cape Town: The UCT Development Unit for New Enterprise.

14. Groenewald, M.J., Mitchell, B., Musengi, S., Naicker, T., van Zyl, J.V. and Visser, K. (2006). Entrepreneurship: fresh perspectives. Cape Town: Pearson Education.

15. Gudlhuza, N. (2012). Plan for the upgrading of informal settlements (2012/13 - 2014/15). Rustenburg Local Municipality.Gudlhuza Development Solutions (Under Bid: Qu/DPHS/0049) www.google.co.za/webhp?sourceid= chrome-instant\&ion=1\&espv $=2 \&$ ie $=$ UTF- $8 \# q=$ Rustenburg + local + Municipality.++ Plans + for + the + upgrade + of + in informal + se [22 August 2015].

16. Habiyakere, E., Owusu R.A., Mbare, O. and Landy, F. (2009). Characterising African immigrant entrepreneurship in Finland. In Sigué, S. (ed).Repositioning African Business and Development for the 21st Century. Peer-Reviewed proceedings of the $10^{\text {th }}$ Annual International Conference held at the Speke Resort \& Conference Centre, Makerere University Business School, Kampala, http://www.iaabd.org/pdf/IAABD2009Proceedings_Final.pdf. [17 June 2014].

17. Hay, D. (2008). The business of craft and crafting the business: strategies for success in the rural craft sector. http:// www.tcd.ufl.edu/Data/Sites/44/media/documents/tropilunch/2011/BusinesofCraftHandbook-lowresolution.PDF [13 December 2014].

18. Hunter, N. and Skinner, C. (2001). Foreign traders working in inner city Durban: survey results and policy dilemmas. School of Development Studies (Incorporating CSDS) University of Natal, Durban. Research Report No. 49.

19. Johnson, R.B., Onwuegbuzie, A.J. and Turner, L.A. (2007). Towards a definition of mixed methods research.Journal of Mixed Methods Research, 1(2), pp. 112-133, April.

20. Kaiser \& Associates. (2003). Strategic recommendations for the development of the craft industry in the Western Cape: discussion guide. Prepared for the Cape Craft and Design Institute by Kaiser \& Associates. CCDI report No 5/2003, July.

21. Kaiser \& Associates. (2005). Western Cape microeconomic development strategy: craft sector study. Overall executive summary. 27 May 2005.

22. Kalitanyi, V. (2007). Evaluation of employment creation by African immigrant entrepreneurs for unemployed South Africans in Cape Town. Unpublished Master's mini-thesis, University of Western Cape, Cape Town.

23. Kalitanyi, V. and Visser, H. (2010). African immigrants in South Africa: job takers or creator? South African Journal of Economic Management, 13(4), pp. 376-390.

24. Khosa, R.M. (2014). An analysis of challenges in running micro-enterprises: a case of African foreign entrepreneurs in Cape Town, Western Cape. Unpublished Master's thesis. Cape Peninsula University Technology, Cape Town.

25. Khosa, R.M. and Kalitanyi, V. (2014). Challenges in operating micro-enterprises by African foreign entrepreneurs in Cape Town, South Africa, Mediterranean Journal of Social Sciences, 5(10), pp. 205-215.

26. Kloosterman, R. and Van Der Leun, J.P. (1999). Just for starters: commercial gentrification by immigrant entrepreneurs in Amsterdam and Rotterdam neighborhoods, Housing Studies, 14(5), pp. 47-57.

27. Levent, B.T., Masurel, E. and Nijkamp, P. (2003). Diversity in entrepreneurship: ethnic and female role in urban economic life, International Journal of Social Economies, 30(11-12). pp. 1131-1161.

28. Mail and Guardian. (2015). Somalis in Soweto and Nairobi, Chinese in Congo and Zambia, local anger in Africa targets foreigners. Mail and Guardian. Retrieved from: http://mgafrica.com/article/2015-02-16-somalis-in-s-africachinese-in-dr-congoand-zambia-anti-state-rage-in-africa-targets-foreigner.

29. Makhitha, K.M. (2015). Understanding The organisational buyer behaviour of craft retailers in South Africa, The Journal of Applied Business Research, 34(2), pp. 501-514.

30. Masonganye, M. (2010). Street trading in Tshwane Metropolitan Municipality: Realities and challenges. Urban Landmark. http://www.urbanlandmark.org.za/downloads/report_street_trading_jan2010.pdf [22 August 2015].

31. Mikolo, Y.C. (2007). Livelihood and income generation from the wood carving trade in the Cape Town area of the Western Cape Province, South Africa. Unpublished Master's thesis, University of Stellenbosch, Cape Town.

32. Minghuan, L. (2000). We need two worlds: Chinese immigrant associations in a Western Society. Amsterdam: Amsterdam University Press.

33. Nieman, G. and Nieuwenhuizen. (2009). Entrepreneurship: a South African perspective. $2^{\text {nd }}$ ed. Pretoria: Van Schaik.

34. OECD. (2010). Entrepreneurship and employment creation of immigrants. http://www.oecd.org/migration/ entrepreneurshipandemploymentcreationofimmigrants.htm [19 July 2014].

35. O’Hagan, T. (2001). Spectacular South Africa: Cape Town. Cape Town: Struik. 
36. Oppong, S.H. (2013). The problem of sampling in qualitative research, Asian Journal of Management Sciences and Education, 2(2), pp. 202-210, April. http://www.ajmse.leena-luna.co.jp/AJMSEPDFs/Vol.2(2)/AJMSE2013 (2.2-21).pdf [10 November 2015].

37. Pahwa, S., Bester, J., Van Nieuwenhuyzen, H., Dawood, G., Pieterse, D., Kane, K., Schlemmer, L., Bot, M., Hamilton, G., Madel, C. and van Eden, R. (2006). Impact of municipality regulations on SMMEs.Development Policy Research Unit Working Paper 06/107. http://www.dpru.uct.ac.za/sites/default/files/image_tool/ images/36/DPRU\%20WP06-107.pdf. [22 August 2015].

38. Peberdy, S. (2000). Mobile entrepreneurship: Informal sector cross-border trade and street trade in South Africa. Development Southern Africa, 17(2), pp. 201-219.

39. RAOSOFT. (2009). Sample size calculator. http://www.ezsurvey.com/samplesize.html [11 January, 2015$].$

40. Rogerson, C.M. and Rogerson, J.M. (2011). Craft routes for developing craft business in South Africa: is it a good practice or limited policy option? African Journal of Business Management, 5(30), pp. 11736-11748.

41. Rogerson, C.M. (2010a). The enterprise of craft: constraints and policy challenges in South Africa, Acta Academica, 42(3), pp. 115-144.

42. Rogerson, C.M. (2010b). 'One of a kind' South African craft: The developmental challenges, Africanus, 40(2), pp. 18-39.

43. Sahin, M., Nijkam, P. and Baycan-Levent, T. (2006). Migrant entrepreneurship from the perspective of cultural diversity.Series Research Memoranda, No. 6, VU University, Amsterdam.

44. South Africa. SAPS, (South African Police Service). (2011). Crime report $2010 / 2011$. http://www.saps.gov.za/statistics/reports/crimestats/20111/crime situation sa.pdf [12 December 2014].

45. Tengeh, R.K. (2011). A business framework for the effective start-up and operation of African immigrant-owned businesses in the Cape Town Metropolitan area, South Africa. Unpublished PhD thesis, Cape Peninsula University of Technology, Cape Town.

46. Tengeh, R.K., Ballard, H. and Slabbert, A. (2011). A framework for acquiring the resources vital for the start-up of a business in South Africa: an African immigrant's perspective, European Journal of Social Sciences, (23), pp. 362-381.

47. Tengeh, R.K. (2013). Advancing the Case for the Support and Promotion of African Immigrant- Owned Businesses in South Africa, Mediterranean Journal of Social Sciences, 4(2), pp. 347-359.

48. UNODC. (United Nation Office on Drugs and Crime). (2007). Annual Report 2007. www.unodc.org/pdf/annual_report_2007/AR06_fullreport.pdf [29 January 2015].

49. Van Eeden, A. (2011). The geography of informal arts and crafts traders in South Africa's four main city centres, Town and Regional Planning Journal, 59, pp. 34-40.

50. Van Rensburg, L.J. (2010). National report into the state of entrepreneurship. Can entrepreneurship be taught/learned? http://www.ideate.co.za/2010/10/20/can-entrepreneurship-be-taught/learned [23 January 2015].

51. Vinogradov, E. and Isaksen, E. (2008). Survival of new firms owned by natives and immigrants in Norway, Journal of Development Entrepreneurship, 13(1), pp. 21-28.

52. V\&A Waterfront. (2013). The V\&A history. http://www.waterfront.co.za/vanda/history [23 January 2015].

53. Wickham, P.A. (2001). Strategic entrepreneurship: a decision-making approach to new venture creation and management. $2^{\text {nd }}$ ed. Harlow, Essex: Pearson Education Limited.

54. Zikmund, W.G., Babin, B.J., Carr, J.C. \& Griffin, M. (2010). Business research methods. $8^{\text {th }}$ ed. Toronto: SouthWestern Cengage/Nelson. 